\title{
Large Unstained Cell Count
}

National Cancer Institute

\section{Source}

National Cancer Institute. Large Unstained Cell Count. NCI Thesaurus. Code C74659.

The determination of the number of large unstained cells present in a sample. 